\title{
French ministries in argument over release of as bestos report
}

[PARIS] Tension is growing between French government ministries over allegations that the publication of a report on the risks of asbestos prepared by an expert panel of INSERM, the national biomedical research agency, has been blocked by INSERM itself, on the instructions of the ministry of national education, research and technology.

Given the enormous economic, social and political stakes surrounding asbestos, the report is the most politically sensitive prepared by INSERM's service of 'collective expertise', created in 1994 to provide quick answers to contemporary questions of public health (see Nature 368, 468; 1994).

A short summary of the 560-page report, Effects on health of the principal forms of asbestos, was hastily released in July 1996 just before the government announced a ban on all forms of asbestos. A working draft of the full report was made available for consultation, pending publication.

But the research agency now says that it has decided not to publish the final report as a book as originally agreed, but simply to place a notice in the next issue of its in-house magazine, INSERM Actualités, informing readers that copies of the final report can be bought directly from INSERM.

The report was commissioned from the INSERM panel by the department of labour relations (DRT) of the ministry of employment and solidarity, and the Direction Générale dela Santé of the ministry of health, on the basis that the final report would be published. The ministry of national education, research and technology, which shares responsibility for INSERM with the ministry of health, had no direct involvement.

Claude Allègre, the minister for national education, research and technology, has been an outspoken critic of the report.

In a magazine article written before he became science minister, Allègre argued that the risks of asbestos had been overestimated, and described the INSERM report as "not glittering, either by its scientific rigour, or by its courage". He has also contested the FFr1.2 billion (US\$200 million) plan to decontaminate the huge Jussieu campus in central Paris, where his laboratory is located, arguing it is unnecessary and perhaps even dangerous.

Several independent sources allege that the office of Claude Griscelli, director general of INSERM, blocked publication of the report while awaiting authorization from the science ministry. The order not to publish the report "came directly from the ministry", claims one INSERM official, an account confirmed by officials at the DRT. Similarly,

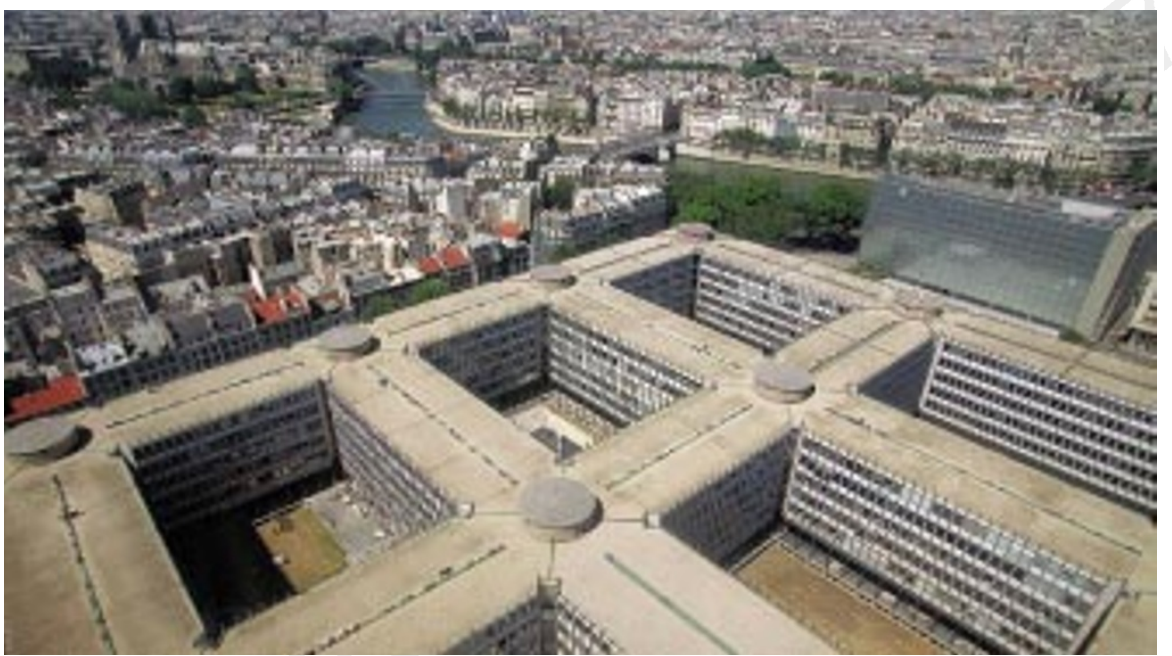

Battleground: plans to remove asbestos from the Jussieu complex in Paris have previously been attacked by the current research minister as unnecessary and perhaps even dangerous.

instructions that INSERM should simply announce that unprinted versions of the report were available came from the science ministry, according to one INSERM official.

Allegations of political interference are denied by Suzy Mouchet, a spokeswoman for INSERM. She agrees that there may have been discussion of the report at the science ministry given Allègre's "particular sensitivity" to the issue, but argues that there is a "subtle distinction" between "discussing it at the ministry, and demanding the authorization of the ministry". She says: "It is normal that there are discussions between Griscelli and Allègre's cabinet."

One DRT official says, however, that the DRT is angry about INSERM's handling of the report, and that it intends to write to the agency within the next few weeks to protest at its failure to publish the report as agreed, and to demand that the decision be revoked.

The official explanation for INSERM's decision is that it considers the market for the final report to be too small to justify the estimated cost of FFr60,000-FFr70,000 of printing, particularly as more than 2,000 copies of the summary have already been distributed.

Vincent Courtillot, Allègre's principal adviser and director of the Jussieu-based Institut de Physique du Globe, says that while he believes the report should be made public, "we don't think it needs to be published as a book [on the grounds of costs]".

Mouchet also argues that the availability of the report will be advertised more widely than it would have been had it been pub-

\section{nature is organizing a halitady conterence on:}

\section{UK university research: Dearing and after}

Friday, 7 November 1997

2.00 p.m. - 6.45 p.m.

Royal Society, 6 Carlton House Terrace,
London SW1Y 5AG ENTRY FREE

The meeting willend with a pane 1 discussion and bef d bw edbyar eception

Admission by ticket only, available on first-come, first-served basis from:

$\mathrm{M}$ a y She ehan, 4 Crinan St reet

London N1 9XW

or m.sheehan@naturecom

Fax: 0171843 4595/6/7
Speakers:

- Sir Ron Oxburgh (Rector of Imperial College, London, and a member of the Dearing Committee)

- Mark Ferguson (School of Biological Sciences, University of Manchester)

- Jean-Patrick Connerade

(Department of Physics, Imperial College, London; member of the executive council, Save British Science)

- Dame Bridget Ogilvie

(Director, The Wellcome Trust)

- Brian Fender (Chief Executive,

Higher Education Funding Council

for England)

- David Triesman (General Secretary, Association of University Teachers) 
lished, as more than 12,000 copies of INSERM Actualités are distributed. She adds that whereas the summary of the report could be easily understood, the full report is highly specialized and could be misinterpreted by "people who don't have the competence to understand it". "There is a big risk in distributing a report of this nature to a wide population," she says. "It poses a problem in terms of communication."

But such arguments are viewed sceptically by the DRT. One official points out that publication of the report was agreed in its contract with INSERM, adding that the DRT "will not accept a unilateral decision taken by INSERM". Moreover, while INSERM has played down the difference between making the report available and publishing it, the DRT considers the distinction is important.

One official from the DRT points out that as it stands the report is "grey literature". This makes it more difficult for scientists elsewhere to obtain it, and risks downgrading its status. "The report must be confirmed by publication; not to do so would throw doubts on its validity," particularly as its contents have been challenged internationally.

Indeed, the French ban, and the contents of the full INSERM report, have already been vigorously contested by the Canadian federal government, and the government of Quebec in particular (see Nature 385, 379; 1997). The French have been criticized for including chrysotile asbestos in the ban; the adequacy of extrapolations of toxicity to lower levels of exposure has also been challenged.

Failure to publish the report would "undermine" the series of measures taken by the government on asbestos, says the DRT official. These were partly justified on the basis of the report's contents. The official claims INSERM's handling of the report raises questions about its "independence" from its political masters. He said: "This is a very serious matter for us, it is shocking."

Researchers involved in the preparation of the report are also unhappy. "It is the first time in my life that I have seen INSERM ask the question 'should we publish or not a report that might not please the minister," says one. "It is of extraordinary gravity."

One member of the scientific board of INSERM says the handling of the publication of the report has been "unusual". "First we say that here we have independent scientific advice, and then we don't publish it because of political reasons," the researcher says, although acknowledging that the report is the most "politically explosive" INSERM has been asked to produce.

Observers point out that Griscelli, who is close to the neo-Gaullist RPR party and whose appointment was widely considered to be political, is in a vulnerable position as his post as director general has been in question since the Socialists came to power in the general election in June.

Declan Butler

\section{US energy offic ial departs w ith a 'get real' w arning}

[WASHINGTON] The senior official responsible for environment, health and safety at the US Department of Energy leaves Washington this week with a warning for scientists: engage with the communities you live in, or face oblivion.

Tara O'Toole, a physician who has spent four years crusading against entrenched practices as an assistant secretary at the department, says scientists need to wake up to what is happening outside laboratory gates.

O'Toole played a key role in initiating a huge, cross-government investigation into the human subjects research that took place in the United States during the Cold War. More recently, she upset some scientists at the Brookhaven National Laboratory with her aggressive approach to environment problems there.

O'Toole practised and taught medicine in Baltimore, Maryland, and then worked on environmental health issues for the congressional Office of Technology Assessment before joining the administration. She was one of a cadre of radical officials sprinkled by President Bill Clinton across his first administration. As this group tires and departs four years is considered a long time in such positions - it is being replaced, in general, by a more orthodox class of Washington official. O'Toole's successor has yet to be named.

"We 'baby-boomers' just haven't been realistic about how difficult it is to change the world," O’Toole reflects. "I hope more people come forward to do this kind of work."

Scientists need to accept that "the political process isn't fair" and yet still engage with it, she argues. "It is very important that scientists get in the game. The community of scientists better do what needs to be done to assure the public that its programmes are properly run."

O'Toole led the Department of Energy's public response when a tritium leak was discovered at the Brookhaven National Laboratory on Long Island, New York, earlier this year (see Nature 386, 3; 1997). The department responded with high-profile investigations into the management of the laboratory, and soon sacked its managing contractor, Associated Universities Incorporated.

Some scientists at the laboratory believe that the department overreacted, giving encouragement to critics who would like to see it shut down. Nick Samios, who retired as laboratory director in March, said at the time: "Tara is trying to be helpful, but it isn't wise to constantly hold these press conferences. He noted that every one of them led to negative publicity for the laboratory.

O'Toole counters that the department

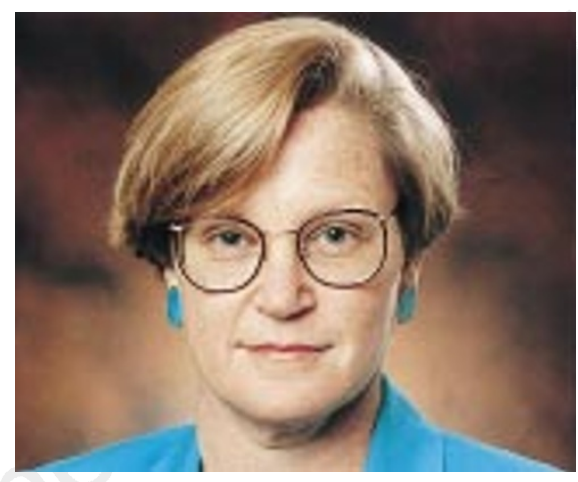

O’Toole: scientists must "get in the game".

acted to save the laboratory from itself by piercing its complacency about the perceptions of people outside. She says she sympathizes with Brookhaven scientists "to some extent”, especially with graduate students whose projects were wrecked by the suspension of reactor-based research there.

"But the root problem was that scientists at Brookhaven were not engaged with the political realities of the community in which they live," she says. "I don't think they yet grasp the peril to the laboratory that is posed by the tritium plume - it isn't a threat to public health, but it sure is to the laboratory."

She also thinks that lessons learned at Brookhaven will eventually come into play for biology, as it comes to resemble 'big science.' "The Human Genome Project is the beginning of 'big biology", O’Toole says. "Science is no longer a cottage industry." She predicts biologists engaged in big science will have to engage the public more effectively.

Energy department watchers say O’Toole will be sorely missed. "She was very thorough and committed and brought an incredible amount of technical knowledge to the job," says one Congressional staffer.

Asked who will continue where she left off at the department, O'Toole replies dutifully that Federico Peña, the energy secretary, and his deputy and probable successor, Elizabeth Moler, "care about openness" and will continue to push for it. But neither Peña, a career politician, nor Moler, a Washington lawyer, is likely to upset the apple-cart at DoE in the manner of O'Toole or Hazel O'Leary, the previous energy secretary.

O'Toole's specialized knowledge helped turn O'Leary's vision of a more open department into reality - especially through the investigation into human subjects research, which eventually embraced the entire federal government. "They fought with the culture [of the laboratories], and it outlasted them," says the staff member. "But they did make a difference."

Colin Macilwain 